\title{
APROXIMACIŌ A EUGENI D'ORS
}

\author{
Eusebi COLOMER
}

«Un dels més grans errors de la meva vida hau. tà estat conèixer personalment Xènius. L'idea! de la nostra generació hauria estat que, en el moment de fer acte de presència en la vida, ens haguéssim trobat amb un Xènius ja clàssic, voltat de tots els atributs de la glòtia, la seva vida con* vertida en llegenda -és a dit, amb un Xènius mort unes dotzenes d'anys abans de la nostra aparició en la terra... Aquesta solució ens hauria evitat el turment de la contemporaneïtat a nosal. tres i potser més encata a ell. El destí d'aquest home haurà estat de no lligar amb els seus contemporanis; en canvi, jo crec que serà adorat pels venidots ${ }^{1}$. Aquestes tatlles, escrites el 23 de juny de 1919, provenen del Quadern gris de Jo. sep Pla. El gran escriptor empordanès, aleshores jove estudiant de dret a Barcelona, hi palesa ja aquella extraordinària barreja de perspicàcia $i$ murrieria que serà després un dels trets caracte. rístics del seu tatannà. La clarividència del seu judici és encara més remarcable, pel fet que $\mathrm{Pla}$ acostuma a parlar de Xènius amb una desimbol. tura un xic corrosiva $i$ àdhuc irreverent. Hi ha un punt, però, en el qual el judici de Pla no ha tesultat exacte: discutir pels contemporanis, Euge. ni d'Ors no ha estat adorat pels venidors. Des. prés de la seva mort una pesada llosa de silenci i d'oblit ha caigut sobre la seva obra. Natural. ment, hi ha excepcions, però, com se sol dit, confirmen la regla. Si aquesta observació és vàli. da en el camp literari, ho és encara més en el filosòfic. Dutant aquests darrers decennis l'interès dels historiadors de la filosofia espanyola, dintre i fora de les fronteres de l'Estat, s'ha concentrat en els dos astres majors d'Unamuno i Ortega. Eugeni d'Ors en restava al marge. Ja és hora de superar aquesta visió esquifida i partidista. No podem quedat-nos eternament reclosos en el binomi Unamuno-Ortega. Cal recuperar per a la història altres figures cabdals de la primera meitat del nostre segle. I entte elles ningú no s'ho té més merescut que el nostre Xènius. Per la cultura catalana aquesta recuperació d'Eugeni d'Ors és d'una necessitat peremptòria. Altrament ens mancaria una anella indispensable per a la com. prensió de la nostra recent història intel.lectual. Hom pot pensar el que li plagui d'Ors i de la se. va obra. Però, com observa també Pla, en la perspectiva de la història, el que ell feu ja uno podrà ser destruït»².

L'individu, ensenya Hegel, és el seu món en tant que seu, és a dir, la unitat de l'ésser donat $\mathrm{i}$ de l'ésser construït, d'allò que hom ha fet d'ell $\mathrm{i}$ d'alò que ell liurament ha esdevingut. L'home no es pot distanciar mai del tot del món cultural $i$ intel-lectual que el sosté i l'encunya, però ćs un home madur i no solament un adolescent que es fa escàpol o diu no, en la mesura en què, bo i acceptant el seu món, s'esmerça a donar li el seu encuny. Els individus veritablement genials són els qui adopten enfront del seu món una actitud alhora passiva i activa, en una paraula els qui en són a l'ensems criatutes i creadors. ¿No us sembla que aquesta visió hegcliana escau exactament al cas de Xènius? Fixem-nos de bell antuvi en el món de la cultura. Quan Eugeni d'Ors va començar la seva aventura intel.lectual, la vida cultural catalana estava sota el signe del moder. nisme. El modernisme és un corrent molt difícil de definir, per tal com s'hi barrejen masses coses, el naturalisme en la literatura, l'impressionisme en la pintura, el simbolisme en la poesia, la tesi sociològica en la política, i tot això, sobte la base d'una recerca apassionada del sentit del misteri. Sense veure-hi, com Joan Fuster, «un coktail manicomial de pretensions metafísiques, evanescències esteticistes $\mathrm{i}$ esclats xatons, amb al. guna gota de redemptorisme social ${ }^{3}$, cal reconèixer que fou una mena de desori que va produir, tanmateix, unes quantes obres mestres. Calia posar ordre i civilitat en aquell desori, sot. metre'l a la primacia de la rá, reinstaurar l'exigència de la feina ben feta, de l'equilibri i de la claredat. Això és el que féu Eugeni d'Ors amb el seu nou mot d'ordre: el noucentisme.

Xènius endegà el nou corrent cultural des d'una secció quotidiana de "La Veu de Catalun. ya» que aparegué, d'ençà del gener de 1906 , amb el nom de Glosari. "El Glosari, escriu Joan Fuster, fou el "butlletí oficial" o l' "acta aposto. licae sedis" del noucentisme, i la seva irradiació damunt totes les esferes de la cultura catalana va produir $-s e$ amb una velocitat enlluernadora. Els breus articles de Xènius esdevenien càtedra i jurisprudència d'un nou "esperit del temps", davant del qual ningú no podia testar impassible. No caldrà que expliquem, ara i ací, l'immens impacte que el noucentisme ha deixat en la darrera etapa de la nostra història intel-lectual. Es un episodi ben conegut. "Un treball admirable de subversió antiprovinciana", segons Pla. No solament això, és clar, però això sobretot» ${ }^{4}$. No 
oblidem, en efecte, que darrera el Glosador hi havia un home d'estat, Entic Ptat de la Riba. El creador de la Mancomunitat, tractava de fer de Catalunya un país curopeu. Contra un estat anacrònic i contra les inc̀rcies provincianes que en provenien, Prat maldà per a establir les bases d'una reestructuració institucional $i$ intel-lectual que fos congruent amb el que aleshores es porta* va en l'Europa burgesa i il lustrada. Per això, en. tre altres coses, confià a d'Ors la tasca de dotar a la Catalunya renaixent d'un sòlid pensament na* cional. I Xènius s'hi esmerçà de la faisó més incsperada, però, de fet, la més ajustada a l'intent de Prat. Va partir del principi que el mitjà més adient per a dotar a Catalunya d'un pensament nacional era el de renunciar al nacionalisme d'espardenya i de bartetina i d'obrir bat a bat portes i finestres a tots els vents d'Europa. En altres termes, d'Ors volguć sctr el menys nacionalistá dels pensadors justament per a servit la causa del nacionalismc ${ }^{5}$. El noucentisme fou, doncs, veritablement segons l'expressió de Pla, un treball admirable de subversió antiprovinciana, encami* nat, però, a una tasca radicalment contràtia, la tasca de la tecosntrucció nacional. La negació esdevenia, com en la dialèctica hegeliana, la condició d'una afirmació.

Com definir ulteriorment el noucentisme? De bell antuvi, sembla un mot sense contorns, gairebé indcfiniblc, tant o més que el mot prece. dent de modernisme. Si pretén designar alguna cosa és només el nou esperit del temps, del segle vintè, en oposició al ja caducat del segle dinovè. Si rellegim, però el Glosari, ens adonarem que el mot no va mai sol. Xènius fa brollar cntoren d'ell tot un doll de mots aparellats $i$ antagontics, com són «natura» $i$ «cultura», «espontani» $i$ «arbitrari», «romàntic» $\mathrm{i}$ «clàssic», etc. A l'arrel de totes aquestes oposicions hi ha el rebuig radical de tot allò que es natural $i$ espontani. Les nacions són cultures, ensenya Xènius. Per això aquell que fonamentés una cultura, com Ramon I.lull, fundava una nació ${ }^{6}$. La cultura, però, com ho diu el mateix mot, és cultiu o conreu de la natura i en aquest sentit és per excel-lència l'antina. tura. La cultura és el resultat d'una lluita contra un adversari dur i obstinat, una lluita en la qual no n'hi ha prou amb la força de la voluntat; cal afegir-ni també una bona dosi d'estratègia. Per l'estratčgia, deia d'Ots, la retòrica es converteix en inspiració, l'oratòria digressiva en dissertació, el treball en fascinació. L'orador es fa. El pocta es fa. I'artista es fa. L'home de ciència es fa. El ciutadà es fa. Aquesta glossa cra el tir de gràcia contra el modernisme. El scu manifest més important, les Oracions de Santiago Rosinyol amb il-lustracions musicals d'Enric Morera, quedava reduit a una simple antigalla ${ }^{7}$. un cop més, però, la negació esdevenia afirmació. La demolició del modernisme obria pas a la construcció del noucentisme. Era com una mena de transmuta. ció de tots cls valors vigents. Contra el tomanticisme Xènius postulava el classicisme. Contra el gust per la dispersió, l'esforç per a l'unitat. Contra l'expressivitat, la bellesa. Contra la música, el dibuix. Contra els corrents, les figures. Contra l'espontancïtat, el to. Contra el llibettinatge, el sonet. Contra el caprici, la norma. Contra la sinceritat, la urbanitat. Contra el verisme, l'arbitra. tietat. Contra l'exabrupte, la gramàtica. Contra el ruralisme, la ciutat. Contra el carrer, la Uni* versitat. Contra l'anarquia, l'autoritat. Contra el popularisme, la civilitat. Contra el trabuc, el somriure. Contra la revolució, la tradició. Contra la barbàrie ibèrica, la civilització mediterrània. Tot quedava sotmès a un sistcma vastíssim de valoracions, una obertura de compàs que anava de la conducta individual als judicis més universals i que tenia com a pedra de toc sense falla l'europeisme a ultrança ${ }^{8}$.

La lliçó que es desprenia del Glosari assolí la seva expressió literàriament més reeixida en la ben plantada. Teresa, l'heroina de la novel-la, és alhora símbol de la raça i dels nous ideals artístics $i$ intel-lectuals del noucentisme. L'essencia de Catalunya s'anomena proporció, harmonia, se. renitat, equilibri, mesura, en un mot, classicisme. La Ben Plantada, doctora d'harmonia, n'és l'encarnació transcendent, com si diguéssim la «idea platònica» de la catalanitàt. Per això passa per la vida del seu autor com una aparició i se'n va finalment cap al cel, deixant com una estcla aquestes alades paraules: "Com les monedes d'un imperi la cara d'un Emperador i la llegenda del seu escut, l'or de la Ben Plantada portarà impresos la seva imatge i el seu verb. Verb de salvació, perquè és de normalitat i de mesura. Jo no he vingut a instaurar una nova llei, sinó a restaurar la llci antiga. No vull portar-vos tevolució, més continuació... Mentrestant, que cadascú desvetlli $\mathrm{i}$ cultivi el que hi ha d'angèlic dins ell, això és, el titme pur i la suptema unitar de la vi- 
da: allò que declarat vol dir l'elegància. Aconse. llaren els romàntics darrers: fes la teva vida com un poema. La Ben Plantada aconsella més tost: fes la teva pròpia vida com l'elegant demostració d'un teorema matemàtic... Tu has d'ésser exem. ple de calma i no et tornaràs infidel al sentit de la proporció. Així et vull, i solament a preu d'aquesta contenció podràs anunciar la meva pa* raula. Vés, doncs, i instrueix-ne les gents, batcjant-les noucentistes en nom de la Teresa»?

Una filosofia concreta no es pot separar mai de I'home que la fa. Ara, en la personalitat de Xè. nius hi ha dos trets, en aparença contraris, que condicionen la seva manera de veure el món: l'esteticisme i l'intel-lectualisme. Tots dos tenen a veure amb la seva condició d'home de la Mediterrània. Com deia ell mateix, no es neix en va vora el Mare Nostrum. No hi ha dubte que en el cátalà el sentiment preval sobre la passió. Una* muno no anava del tor desencaminat en dir-nos a la cara, amb aquella franquesa tan basca que el caracteritzava: «Sempre sereu uns sentimentals. L'estètica us afoga». Ês clar, l'estètica pot convertir-se de vegades en un parany. En les darreries del segle XIX un sentimentalisme tou i cri* daner ens hauria pogut portar al carretó sense sortida de l'anarquia. Però no es pas així com d'Ors entenia l'estètica. D'Ots intentava - no sé si sempre ho aconseguí- fer passar la sensibilitat pel sedàs de la raó. Aleshores l'estètica, lluny d'ofegar l'esperit, li permet de respirar a ple pulmó, li permet sobretot de copsar una altra cara de la realitat, l'ésser com a bell, que altrament li restaria amagada. En qualsevol cas Xè. nius pertany al grup reduït i selecte de pensadors dotats de sentit per a la bellesa. Ell té poc d'Aristòtil o de Sèneca i molt de Plató i sobretot de Goethe. El seu fort no es la metafísica ni l'ètica, sinó l'estètica. La predilecció de Xènius per al gran poeta de Weimat és ben coneguda. En una de les seves darreres conferències intitulada « $\mathrm{Si}$ Goethe fos filòsof» d'Ors aseria amb èmfasi que hom havia comès una gran injustícia amb el poe. ta alemany en no concedir-li la significació que té com a filòsof. En els manuals d'història de la filosofia els autors salten sense cap remordiment de Kant a Hegel $\mathrm{i}$ abandonen Goethe a la fossa comuna de la poesia. Ara, concloïa d'Ors, si hom no anomena filòsof Goethe, caldrà anomenar-lo filosof $\mathrm{i}$ mig. Que Goethe fos o no el que pensa Xènius, no ens interessa aquí d'escatir-ho. El que ens importa és subratllat que d'Ors, autor d'uns quants papers sobre filosofia pura, no considerés una cosa estranya a la seva tasca l'intent de mirar el món amb els ulls de Goethe, una de les personalitats estètiques més refinades que recorda la història de la huma. nitat. És que d'Ors era poeta? Com en el cas de Balmes les seves curtes incursions en el país de la poesia foren generalment un desastre. Però Xè. nius era poeta en un sentit més profund. Ho era pel seu refús apassionat de reduir l'essència de les coses a la dimensió de la pura racionalitat. En una ocassió escoltava algú que deia que l'aigua, en darrer terme, no era res més que $\mathrm{H}_{2} \mathrm{O}$ i cll afegí amb gràcia: $\mathrm{H}_{2} \mathrm{O}$ i una cançó. Les coses són el que són $i$, a més a més, tenen un punt de be. llesa. Tot pot ser-ho de bell: una simple gasetilla, un treball de fusteria $\mathrm{i}$ àdhuc una reculllida d'escombraries si es duu a terme amb perfecció $i$ amb gust per a la neteja ${ }^{10}$.

Hem recordat suara Goethe. Ens cal, però, fer també cas d'una altra veu, molt escoltada a casa nostra en les darreries del segle dinovè, una veu que no feia gaires decennis havia Ilançat el crit: Abaix la metafísica i la moral i amunt la bellesa! Em refereixo, no cal dir"ho, a Nietzsche. S'ha parlat molt de l'influx de l'autor de Així parlá Zaratustra en el Maragall jove. De la relació entre Nietzsche i d'Ors, en canvi, no se n'ha dit res. Hom s'ha limitat a cercar en el dionisisme de Nietzsche un precedent de la concepció d'orsiana de l'obra d'art com a acte arbitrari. Tanma. teix, hi ha motius per a sospitar que l'influx de Nietzsche sobre el pensament de Xènius va molt més enllà. Nietzsche era aleshores omnipresent en tots els cenacles intel-lectuals del país. La generació castellana del 98 no es pot entendre sense ell. Després de dos llargs segles de predomini de la raó, hom erigia l'art i la bellesa en valor suprem. ¿No era Nietzsche el qui havia escrit: «Tenim l'art perquè no ens enfonsem en la veritat?». $D^{\prime}$ Ors evidentment no anirà tan lluny. L'immoralisme de Nietzsche, la seva subversió de tots els valors vigents, la seva exigència de pensar contra la raó, la seva voluntat d'alliberar. se de tota certesa, per a no parlar del seu antiso. cratisme $i$ anticristianisme, li havien de fer basarda. D'Ors no era un home avesat, com Nietz. sche, a ballar sobre el caire de l'abisme. Amb tot i això, Xènius enlairarà a tall de bandera l'ideal de la «ciència com a art». Res no interessa tant els 
mediterranis com «afirmar en tota cosa la victòria de l'element estètic de l'art. Nosaltres no podríem transigit amb una Europa antiartísticas ${ }^{11}$. D'Ots no negarà la veritat en nom de la bellesa $i$ de l'arbitrarietat, però farà de la bellesa una dimensió de la veritat. Per a canonitzar una filosofia no $n$ 'hi ha prou amb la seva finalitat o amb la seva utilitat: la font pregona de la seva veritat tau en la seva bellesa, en la seva raó estètica. I sobretot Xèrius farà de l'art l'objecte ptedilecte de les seves reflexions. Es segurament en aquest camp on d'Ors ha produït autèntiques obres mestres. No és sense motiu que el seu assaig Tres boras en el Museo del Prado ha conegut un grapat d'edicions i ha estat traduït a les principals llengües cultes. Josep Pla té raó: la sensibilitat estètica és el més gran do que li fou concedit a d'Ors per la vida ${ }^{12}$.

La sensibilitat d'orsiana, ja ho hem dit, té tibets $\mathrm{d}$ 'intel-lectualisme, fins i tot de cartesianisme. Xènius fou un home amarat de cultura francesa. Coneixia com pocs els grans clàssics del segle divuitè, una época que no en va s'anomena des lumières i en la qual el predomini de la raó sobre les altres facultats de l'esperit assolí un extrem inigualable. D'ací li ve segurament la seva mania per l'ordre, la claredat, el sistema. En $L a$ Ben Plantada, en parlar de les germanes de Teresa, observa que «la raó humana troba un pregon plaet a distribuir cada un dels aspectes de realitat que contempla en tres parts ben ordenades» ${ }^{13}$; en encetar la descripció de la seva herö̈na avança la quintaessència de la seva preceptiva literària: «No cantis res,. no exaltis tes, no barregis res. Defineix, compta, amida. Poguessis dir com Stendhal, foll no obstant de passió per l'església de Sant Pere de Roma: Voict des détails exacts ${ }^{14}$. La primera cosa que ens cal, solia dir, «és sortir de la confusió». I també: «Es vulgui o no, tota autèntica filosofia és un sistema, és a dir, una organització total, una estrucrura, una arquitecturas ${ }^{15}$. Hem fet esment suara de les arrels franceses de l'intel.lectualisme de Xènius. Ell, però, el relacionava normalment amb el marc cultural del món mediterrani. Claredat mediterrània contra les boires nòrdiques, heus ací la fórmula que contenia la seva missió i potser, fins i tot, la de Catalunya. D'Ors ho expressava de vegades amb la coneguda boutade: descobrir el Meditarrani. E s a dir: «Descobrit el que hi ha en nosaltres de mediterranis i afirmar-ho de cara al món i extendre-ho, en obra imperial, entre els homes». Ara bé, el Mediterrani, per a Xènius, era no solament la llatinitat, l'herència cultural de Roma, sinó també l'hel-lenisme, el llegat immens $i$ excepcional de Grècia. "Atenes és meva $\mathrm{i}$ amb més raons que en aquella hora cn què uns catalans hi regien el ducat». I cl Mediterrani eta sobretot el do de la llum, l'exigència no tant de sortir de la tenebra, com de lluitar contra els qui s'hi emparen. «Hi ha la raça d'aquells que, com Goethe, malden per a arribar de l'ombra a la llum. Però hi ha també la d'aquells altres, dels bons filis d'Hèlios, que l'han rebuda gratuïtament i patrimonialment». No cal dir que Xènius es considerava un exemplar privilegiat d'aquesta segona raça d'homes. Per això va donar a la seva tasca intel-lectual el nom d'sheliomàquia» i va adoptar com a patró Sòcrates, el filòsof de la majèutica, l'home que ajudava als altres a donat a llum, el llur esperit, els conceptes.

Nascut un any abans que Ortega, Eugeni d'Ors serà, com aquell, un pensador del nostre segle que no pot ser comptès sinó des de l'artelament en el segle passat. De fet, la pregunta que rau en el fons del pensament d'ambdòs filòsofs és la pregunta típica del pensament curopeu d'entre segles: com integrat la raó en la vida. Només és diferent llur punt de partença. Ortega venia del neokantisme; d'Ors, en canvi, del pragmatisme. En el sentit estricte d'aquest mot, el pragmatisme és un corrent filosòfic otiginat als Estats Units d'Amèrica entorn de Charles Sanders Peitce, William James i John Dewey. El propòsit centtal del grup fou formulat per Peirce en el treball intitulat How to make our ideas clear, de la manera següent: «Concebem l'objecte de les nostres concepcions considerant els efectes que poden set concebibles com a susceptibles đ'abast pràctic. Així, doncs, la nostra concepció d'aquests efectes equival al conjunt de la nostra concepció de l'objecte». Això era, clat i català, fer dependre la veritat de la seva urilitat pràctica. El pragmatisme, com és ben palès, era una manera de pensar que es corresponia exactament amb la típica american way of life. Amb tot $i$ això no li mancaren seguidors en la vella Europa: F.C.S. Schiller a Anglaterra, W. Jcrusalem a Alemanya i el primer Giovanni Papini a Itàlia. Ês difícil d'escatir el camí a través del qual aquesta concepció utilitària del coneixement arribà fins al jove Xènius. Que d'Ors conegué el 
pensament de William James és un fet indubtable: altrament no s'hauria pres la molèstia de refutar-lo en les pàgines d'un dels seus trebalís primerencs: Religio est libertas. No oblidem tampoc que Nietzsche, un autor ben conegut de Xènius, sense ser estrictament un pragmatista, definia tanmateix la veritat com «aquella mena d'error sense cl qual una determinada espècie d'éssers vivents (evidentment, els homes) no poden viute». Finalment, com a actitud d'esperit, el pragmatisme s'avenia admirablement amb la pruija d'eficàcia de la societat contempòrania. Deixem-nos de teories, pensava el bon burgès, $\mathrm{i}$ toquem de peus a terra: les coses valen d'acord amb el que podem fer amb elles.

En qualsevol cas és un fet que d'Ors comença a filosofar en l'horitzó històric del pragmatisme. El seu intent és clarament de superació: testaurar la vella tradició intel-lectualista del pensament occidental. Però, amb un agut sentit històric, s'adona immediatament que la millor manera de deixar quelcom entera és donar decididament un pas endavant. «El que ha estat és. El que aquells corrents ens han portat no ens és possible de desconèixer-ho. Ens cal, si, deixar-los enteta, però això desprès d'haver passat per ells» ${ }^{16}$. L'in. tel-lectualisme al qual aspirem és postpragmàtic $i$ té en compte el pragmatisme» ${ }^{17}$. D'Ors el tingué tan en compte que en una altra obra primerenca, La fórmula biológica de la logica, no dubta d'escometre l'enemic amb les seves mateixes armes i li mostra que la raó és útil a la vida. La raó es una diàstasi -més tard dirà: és com una diàstasi- que mitjançant la seva tasca d'assimilació anul.la la toxicitat del món i fa possible la vida. Posteriorment, Xènius considerarà que entre la raó i la vida la segona és la més forta, però la primera la més excel-lent. Que sigui, doncs, la raó la que domini, però sense excloure la vida. La primacia de la raó és indiscutible, però és la primacia d'una raó inscrita en la vida.

"Pels seus fruits els coneixereu», diu l'Evangeli. Si quelcom no serveix per al que havia de ser. vir cal rebutjar-ho. Aquesta, pensa d'Ors, és la lliçó que es desprèn del pragmatisme. I cal que la filosofia l'aprengui, aquesta lliçó. Per això la filosofia d'orsiana no serà una filosofia de càte. dra o de manual, sinó, per dir ho així, una filosofia utilitària, una filosofia que serveixi per a la vida. Un iove crític musical francès havia dit: «Prou de cignes, prou de llacs, prou de parcs: vull una música en la qual pugui entrar-hi com en la meva pròpia casà. De manera semblant d'Ors vol una filosofia humil, quotidiana, usual, una filosofia en la qual l'home es trobi com a ca. sa. Es en aquest sentit que d'Ors parlarà de la «filosofia de l'home que treballa i que juga» i també d'una «metafísica d'estar per casa». Així. en la darrera pàgina del Glorari de 1906 cs feia aquesta pregunta: «Què has fet? Què ets tu, glo. sador? Has fet una metafísica d'estat pet casa. Ets un metafísic d'estar per casa ${ }^{18}$.

D'Ors subratlla, doncs, el binomi contemporani filosofia $i$ vida. Ell no concep ni una filosofia al marge de la vida, ni una vida sense filosofia. Cal que ambdues coses vagin sempre juntes sense inúrils problemes de precedències. «Primer viure, després filosofar?», prcguntava Xènius en una glosa escrita en 1910 per a l'Almanacco del Coenobium de Lugano. I responia: "Ho nego. En això no conec ni abans ni després. Anomeno filòsof Publius perquè viu en la consciència de l'eternitat del moment» ${ }^{19}$. En cada obra de l'ho* me que traballa o que juga s'amaga una liavor d'eternitat. Filosofar vol dir descobrir i cultivar aquesta llavor, fer que broti i faci florida. Per a d'Ors, «res d'humà no és aliè a la filosofia». El seu pensament traurà botí de qualsevol cosa $i$ ho transformarà en substància d'eternitat. Com li agradava de dir, convertirà «l'anècdota en categoria».

Per a dur a terme aquesta operació d'Ors compta amb dos mitjans: el diàleg i la ironia. $\mathrm{Si}$ filosofar és collir les flors d'eternitat del moment fugisser, cal que el filòsof cstigui scmpre alerta, sempre a punt per a copsar el misșatge que li porten els esdeveniments. El pensament esdevé aleshores diàleg. Diàleg d'un home amb un altre, d'una filosofia amb una altra $i$, en darrer terme, diàleg del filòsof amb el seu alter ego, de la consciència amb la superconsciència 0 , com deia Xénius, amb l'«àngel». Aquest diàleg, però, com li esdevenia a Sòcrates, tindrà sempre un punt d'ironia. El pensament dialogal no reposa en la veritat que acaba de trobar. La destrueix $a m b$ un lleu somriure, per a cercar-ne de bell nou una de més gran. Ironia vol dir, doncs, posició d'alteritat. Significa alhora tradició i llibertat d'esperit, conservació de la fórmula enfront de l'anarquia romàntica, però també manteniment d'un marge de llibertat que impedeixi que es petrifiqui en dogma i escolàstica. La ironia man. 
té scmpte obertes les portes i finestres de l'espe. rit i, com dcia d'Ors, troba la síntesi en la matei. $x a$ tesi $^{20}$.

D'Ors dugué a terme aquest diàleg irònic amb dos grans corrents del pensament europeu: cl ra* cionalisme que s'obte amb Parmènides i es clou amb Hegel i l'irracionalisme biologista o intuicionista de Ludwig Klages i d'Henri Bergson. Enftont del raonament abstractc del racionalis. me o de la intuïció vital de l'irracionalisme, d'Ors adopta ironicament una posició de síntesi: la veritat només la copsa el pensament immers en la vida, és a dir, no la raó freda, abstracta, conceptual, sinó la intel-ligència concreta, figurativa, eidètica, a mig camí entre l'sesprit de géometrie» i l'acsprit de finesse» de Pascal, una intel. ligència que no concep ni l'universal abstracte ni l'individual concret, sinó precisament l'universal concret, la idea encarnada, l'ideal vivent. Filosofar, deia Xènius, és pensar amb els ulls. Aquest fou el secret d'allò que Renan ano. menava el «miracle grec». Wils grecs foren uns ho. mes que pensaven amb cls ulls. Per això foren capaços de trobar en les coses concretes $i$ fugisse. res la seva forma ideal, cterna, el seu eidos. D'Ors no opina altrament. Pet això propugna la tornada a la mancta de fer dels grecs, a una «raó concreta» o «intel ligència plena», que no es deslligui del llenguatge i de l'acció, que no sigui ni materialista ni massa esquiva en el seu espiritua. lisme, que cerqui la forma universal en la figura concreta i viva, un tipus de pensament que ell acostumava a expressat amb el mot, tan català, de «seny».

Modernament, l'hermenèutica filosófica ha cridar l'atenció sobre la importància de les «for. mes» del pensament. Quina és la forma del pensament d'otsià? Ell mateix ens dóna la resposta a aquesta pregunta amb la seva coneguda doctrina sobre l'esquema circular de la filosofia. En oposició a les ciències particulars, l'esquema del cer. cle. En l'escala cada graó recolza en l'anterior i, finalment, tota l'escala en el sòl. La filosofia, en canvi, no recolza en res, per tal com la seva tasca és donar compte de tot. La seva forma, com ja deia Hegel, és la del cercle que comença i acaba en cll mateix. Un cercle legítim i no viciós, en la mesura en qué és prou ample per a abarcar-ho tot. D'Ors fa seu, doncs, el punt de vista de Hegel però amb una correcció important, que ell solia anomenar la «reforma kepleriana» de la fi- losofia: el cercle no té un sol centre sinó dos i es converteix en el el-lipse. La fórmula recorda a Kant i la seva famosa «revolució copernicana». El problema de la filosofia en tempos de Kant era el de la relació del concixcment amb els seus ob. jectes. Kant va prendre peu de la nova imatge del món de Copèrnic per a donar una volta de campana a la problemàtica filosòfica: no són els objectes els qui determinen el coneixement, sinó el coneixement el qui determina cls objectes. Ara, pensa d'Ors, el problema de la filosofia és un altre: es tracta de superar les dues posicions antitètiques del racionalisme i de l'irracionalis. me i d'integrar la raó en la vida. Per això, imitant la comesa de Kepler, el qual va substituir en l'astronomia el cercle per l'el-lipse, d'Ors vol descobrir en la filosofia la nova «òrbita de la raó» que se situï, en relació amb cl vell racionalisme, com l'el-lipse respecte al cercle. Aquesta òrbita tindrà dos subcentres, la raó i la vida, però reduïs a la unitat per mitjà de la raó concreta i vi. vent, és a dir, del seny ${ }^{21}$.

Només ens resta descriure breument l'arquitectura del sistema. Aquesta no té res d'artificiosa, ans coincideix, senxillament, amb el desenvolupament de la llavor originària del pensa. ment d'orsià. Bergson, en un text molt apreciat per d'Ors, parla de l'experiència pregona que rau en cl fons de tota filosofia. Aquesta experiència s'expressa després amb les formes $i$ els conceptes propis de cada època, però la grandesa d'un pensament, més que d'allò que «diu», de. pèn d'allò que ha «vist» o "experimentat». Des. cartes, per exemple, féu l'experiència de la certe. sa que acompanya inevitablement tot acte de conscic̀ncia i l'expressà en el principi: cogito, er. go sum. ¿Quina és l'experiència pregona, originària, de la qual depèn el pensament sencer d'Eugeni d'Ors? Fis una experiència que està a l'abast de tothom, ja que és pròpia de l'home que treballa $\mathrm{i}$ que juga, i que s'expressa amb aquest altre principi: operor, ergo sum cum ali. quo alio. D'Ors ha reprès moltes vegades aques. ta experiència bàsica, però mai no ho ha fet amb tanta claredat, senzillesa i convenciment com la primera vegada. Penso en el breu assaig intitulat Religio est libertas que d'Ors presentà en $1908 \mathrm{al}$ III Congrés Internacional de Filosofia de Heidel. berg. Davant la puerilitat de certs corrents contemporanis, el pragmatisme principalment, que volien portat la religió als laboratoris de psicolo. 
gia experimental, d'Ors distingeix en el fet religiós les expresions externes, que hom pot exami* nar com qualsevol altre fet de consciència, i la consciència mateixa que les supotta i se situa per això mateix fora d'aquelles òrbites insignifi. cants. La religió, allò que ens lliga amb Déu, és en el seu santuari més íntim libertas, acte de la llibertat. Petò, afegeix d'Ors, la religió és llibertat perquè el jo és llibertat, perquè en el fons de tota acció hi trobem sempre un jo ensibornable, un jo que s'escapa com una anguila de les xarxes cientifiques o experimentals amb les quals voldríem agafar-lo, un jo que és el fons irreductible que testa dempeus fins $i$ tot quan hem pesat, mesurat $i$ examinat totes les seves expressions, un jo que només podem definir per la negació de tot condicionament $i$ de tota fatalitat, és a dir, per $f a$ idea de llibertat.

Imaginem, en efecte, un llenyataire que col. peja un arbre amb la seva destral. Es tracta d'un fet de treball senzill, pintoresc, plàstic. L'home vol abatre l'arbre i l'arbre es resisteix a ser aba* tut. L'experiència viscuda pel llenyataire pot expressar-se amb aquests termes: «Heus ací dos exèrcits: d'un cantó jo, el meu desig, el meu braç, la meva força, la meva destral i de l'altre l'arbre, amb la seva resistència, la seva duresa, les atrels que s'endinsen en la terras 22 .

En el fons d'aquesta experiència hi ha els dos grans principis de la filosofia: un «jo» que és po. tència i llibertat i una "naturalesa» que és tesitència i fatalitat. Si elevem aquesta experiència a principi, la fótmula podria ser aquesta: «El que jo vull $i$ el que s'oposa a allò que jo vull». No cal dir que tot fet humà de treball $i$ de joc pot reduir-se a aquesta formulació. La vida no es duu a terme sinó mitjançant una lluita incessant amb el món que ens rodeja. Respirar és guanyar con. tínuament una batalla. Ara, si ens hi fixem bé, ens adonarem que el llenyataire no ha expressat exactament els límits de la seva expetiència. Ell havia dit: "D'un cantó jo, el meu desig, el meu braç, la meva força, la meva destral» ${ }^{23}$. El mateix llenguatge s'ha vist forçat a distingir entre el pri* mer terme i els següents, entre el jo inadjectivat $i$ els altre termes designats amb una adjectiu de propietat que els posa en relació amb el jo. Això vol dir que en relació amb mi mateix les altres coses meves no són tan meves com semblen. Per al llenyataire el braç, la força, pertanyen a la ma. teixa família hostil que el món exterior: aquestes coses són també fatalitat. El meu cos cau sota l'acció dels meus sentits, com cls altres objectes del món i com aquells m'cposa resistència. Absolutament parlant, jo no sóc el meu cos. Per motius anàlegs cal eliminar també de l'esfera estricta del jo el temperament, la tendència, la ca* pacitat intel-lectual, etc. Totes aquestes coses $m$ 'han estat donades, són «dades» amb les quals haig de comptar $\mathrm{i}$ que de vegades m'oposen també resistència, almenys per raó de la seva li. mitació. El desig personal no es donaria per satis. fet a menys de posseir una intel-ligència infinita . Jo no sóc encara tot això. ¿Seté potser almenys la meva volició? Tampoc. ¿Qui no voldria set un home enèrgic? Jo voldria voler, diu el dèbil, però com fer-ho? També en la voluntat hi ha un punt de resistència, de fatalitat. Al llarg d'aquesta anàlisi, que recorda el que Descartes dugué a terme en relació amb la possibilitat del dubte, d'Ors ha anat tornant al món, a allò que jo no sóc, tot allò que era meu. Resta, però, una tealitat. Jo sóc, doncs, el qui vull o no vull, el qui faig o desfaig, el qui m'imposo com a àrbitre no solament al món $\mathrm{i}$ als seus objectes, sinô àdhuc a mi mateix. La llibertat és el nucli darrer, intim, ensibornable, irreductible, de la persona ${ }^{24}$.

Hem arribat a un punt des del qual no ens costaria gens de reconstruit l'edifici sencer del pensament d'orsià. Acontentem-nos amb fixar les seves parets mestres. 'Tenim a la mà els dos protagonistes del drama de la vida i del diāleg de la filosofia. D'una banda, el jo, la potència, la llibertat; de l'altra la naturalesa, la resistència, la fatalitat. L'anàlisi del jo ens portaria a la poètica (de poiesis = creació), a l'acció de l'home per a dominar la naturalesa i per a domar-se a si mateix, fins a assolir un element de pura personalitat, de llibertat immaculada que d'Ors, figurativament, anomena l'àngel. Ser home, en aquest context, és tendir a esdevenir àngel. Viute ês desvetllar un àngel per a infantar-lo en l'eternitat. L'anàlisi de la naturalesa ens portaria a la pa. tètica (de pathos = passió), a l'estudi del món, de la machina mundi, com una màquina que no és cap màquina, en la qual tot fenomen és un epifenomen, fins arribar, en darrer terme, a un element de pura inèrcia, allò que d'Ors figurativament anomena el pecat original. Si l'home s'entén des de l'ideal de l'àngel, la naturalesa, al seu entorn només es pot entendre des de l'antiideal del pecat. El seu desordre actual pressuposa 
un ordre originari, del qual ha decaigut. Com els neoplatònics i el darrer Schelling, d'Ors explica la naturalesa des de l'esperit. La naturalesa és una mena de tesidu de l'espetit, la barrera que s'oposa a l'home i el força a refinar-se i a perfeccionat-se. Com ho ensenya la Ben Plantada: «això que és dir la natura i on la vostra feblesa us fa raure a cada pas, no és altra cosa que la cendra que deixen els ideals quan pugen, gosadíssims, fins al cel fi, i el seu residu i escombrim. ¿Has vist alguna vegada, quan els infants, pet festa, es donen a encendre aquests àgils enginys de foc que han per nom coets, com, mentre puja aire amunt la daurada estela, cau a terra alhora quelcom de ja inútil i de socatrimat, una !leugeta desferra? Doncs, d'aital cendra és formada la natura que caigué de les idees quan ascendien» ${ }^{25}$. Resta encara el diàleg de l'home amb el món. L'estudi de les tres formes possibles d'aquest diàleg, segons que l'home actuï com a coneixedor (homo sapiens), com a valorador de la realitat d'acord amb criteris estètico-morals (homo ludens), o com a transformador i productor (homo faber) dóna lloc a la dialectica o també a la ciència de la cultura. Ês aquest el camp on el darter d'Ors va esmerçar preferentment la seva activitat intel lectual. En tenim la prova en el manuscrit pòstum, publicat després amb el nom de El secreto de la cultura, on d'Ors desenvolupa una grandiosa visió de la història cultural de la humanitat que pet la seva amplària ens portaria a pensar en Hegel si el nostre autor hagués treballat amb categories menys estàtiques i més dinàmiques ${ }^{26}$.

En la personalitat d'Eugeni d'Ors, com ho ha observat G. Diaz Plaja, hi ha una certa «infidelitat» que explica potser l'oblit de què ha estat objecte per part de les generacions posteriors. La seva lluita per la claredat i la serenitat clàssiques delata, com ho reconeix Aranguren, una ànima barroca $i$ apassionada. Entre l'home i el pensador hi ha un trencament frapant. Josep Pla, en el seu Quadern gris, ho formulava d'una manera difícilment superable, "Un home que s'ha passat la vida predicant el classicisme, la normalitat, la continuació, la superioritat de la categoria sobre l'anècdota -i de fet no és més que un mer anecdòtic, un original, un capriciós, un estrafolari, un romàntico ${ }^{27}$. No ens escandalitzem massa fâcilment d'aquesta contradicció. L'historiador de la filosofia no se n'esdacandalitza: hi està massa acostumat. Entre les idees d'un home i la seva vida hi ha sempre qualque telació, però de vegades és d'oposició, de contrast. Com deia el mateix Xènius, «cadascú s'assembla a aquell dimoni que tracta de vèncer». Aleshores, el pensament d'Eugeni d'Ors haurà estat potser l'expressió de la seva lluita per vèncet el seu dimoni i per desvetllar el seu àngel. Això dóna a la seva figura una grandesa molt superior a la d'un lluminós hal. lo olimpic, necessàriament d'oripell.

\section{NOTES}

1 J. PI.A, El quadern gris. Un dietari (Obra completa, I), Barcelona 1969 , p. 692 .

2 J. PLA, Homenots (Primera sèrie), Barcelona 1958, p. 161.

3 J. Fustler, Notes per a una introducrió a l'estudi de Josep Pla, a J., Pla, El quadem gris, p. 34.

4 lbid., p. 28.

5 Cf. J. Carrfras Artau.J. Tusquets Terrats, Aports hispaniques à la Philosophie chrétienne de l'Occident, Lovaine-Paris 1962, p. 185.

'Cf. J. M. CAPDFVlLA. Eugeni d'Ots. Etape barcelonina (1906-1920), Batcelona 1965, p. $72 \mathrm{~s}$

${ }^{7}$ CE. J. PLA. Homenots, p. 145.

$8 \mathrm{Cf}$. ibid., p. $145 \mathrm{~s}$.

9 La Ben Plantada, Barcelona 1958, p. 142+144.

$10 \mathrm{Cf}$. J. IR1ARTE, Eugenio d'Ors o la claridad mediterränea, a: Razón y Fe, 150 (1954), p. $436 \mathrm{~s}$.

${ }^{11}$ La filosofia del bombre que trabaja y que juega. Antologia filosôfica de E. d'Ors por R. Rucabado y J. Farrấn, Barcelona 1914, p. 51.

12 CfJ. Pla. Homenots, p. 159.
13 La Ben Plantade, p. 57.

14 Ibid., p. 19.

is F. LEFEVR, Eugenio d'Ors, a: Une beure avec..., V, París, 1929.

16 La fllosofia del hombre que trabaja y que juega, p. 19.

17 Ibid. . p. 29.

18 Glosari (1906-1910), Barcelona 1950, p. 21. $109 \mathrm{~s}$.

19) La filosofia del hombre que trabaja y que juega. $\mathrm{p}$.

20 CF. J.L. ARANGUREN, la flosofía de E. d'Ors, Madrid 1945, p. 33 ss.

21 Cf. ibid., p. $130 \mathrm{ss}$.

22 Estudios filosóficor. Religio est libertas, Madrid 1925. p. 16.

23 Ibiơ., p. 21.

24 Cf. ibid. 28 ss.

25 La Ben Plantada, p. $140 \mathrm{~s}$

26 Cf. sobre el tema E. ROJO PEREZ, La ciencia de la culiure. (Teoría historiológica de E. d'Ors), Barcelona 1963.

27 J. PLA. El quadern gris, p. 693. 